\title{
THE ANALYSIS OF THE STATE AND DEVELOPMENT PROSPECTS OF THE MIDDLE CLASS IN UKRAINE
}

\author{
Yana SALO' \\ Odessa National Economic University, Ukraine
}

\begin{abstract}
The purpose of the paper is to study and represent the current state of the middle class in Ukraine, the problems of its formation and development prospects in the future with the definition of the complementary set of internal and external factors of its formation. Methodology. The survey is based on statistical data from open official sources, which makes it possible to confirm the thesis of the critical proportion of the middle class in Ukraine. Besides, the data are obtained from electronic sources, the State Statistics Service of Ukraine. During the study, the paper uses analytical articles on the economic development of the middle class in Ukraine. The results of the survey shows that the middle class is critically low for stable functioning of Ukraine's modern economy. One of the main problems of the middle class development is the absence of state support of small and medium-sized businesses. The government with the repressive model of the economy in relation to business-oriented monopolization was formed in Ukraine. The distribution of the «shadow» model of social and economic relations leads to the limitation of legal opportunities of employment and income. Besides, it complicates the development of small and mediumsized businesses. As a consequence, the number of entrepreneurs and small business owners are constantly increasing, but due to the absence of a favorable business climate a significant number of small businesses were forced to move into the shadow. The peculiarity of the formation of the middle class in Ukraine is that its social basis in contrast to Western Europe is not the owners, but employees. We have a unique situation, when most of the highly skilled workers (the representatives of the spheres of education, health, public administration), which should be the core of the middle class, in terms of income are on the verge or below the poverty line. The level of wages of such specialists does not even correspond to the national average. Practical implications. On the way to the successful modernization of Ukraine in the short and long-term priority business and investment climate is favorable. This, in its turn, cannot be implemented without the improvement of the state management system in the field of entrepreneurship. Policies to promote the formation of the middle class in Ukraine should rely on the support of the working population, providing outstripping wage growth, strengthening the position of highly skilled workforce, as well as supporting entrepreneurship. The formation of the middle class in Ukrainian society must be realized not through the creation of principally new social grouping, but through the gradual transformation of corresponding social groups and their way of functioning. Value/originality. The survey is conducted to clarify the concept of the status of the middle class in Ukraine. The reasons for the low level of the middle class in Ukraine are identified on the basis of the data obtained. The resulting research findings make it possible to propose measures for the development of the middle class in Ukraine, namely - the development of small and medium-sized enterprises and the support of working population, considering the interests of the middle class.
\end{abstract}

Key words: middle class, economic development, small and medium-sized business, society, Ukrainian economy,

JEL Classification: J23, J38

\section{Introduction}

Class differentiation of society is typical for any country. The gradation of social communities is a positive factor for the country developing. At the same time this factor is an indicator of progress, defining thereby the level of economic and social level of citizens.

Over the long time Ukrainian analysts have been disputing over the reasons of class division and conditions of formation and increase of the middle class in Ukraine. Academic-theoretical and applied interest to conduct the research of this subject is the ambiguity of the middle class positions and its place in Ukrainian modern society.

The middle class is an objective term for functioning of strong and stable society and consequently of the state. Many analysts consider this class as a guarantee of politic and economic stability in society.

\footnotetext{
Corresponding author:

${ }^{1}$ Department of Human Resources Management and Labour Economics, Odessa National Economic University.

E-mail: saloiana35@gmail.com
} 
As a rule the middle class includes representatives of small and medium-sized businesses as well as representatives of middle and lower structural units of management, creative occupations, advocates, qualified specialists, educationalists, doctors etc. These categories of population are the most active and predicted part of society. In comparison to richer and poorer classes, the action of the middle class is rational on the market.

At the present stage the middle class is supposed to be the basis of the society in developed and democratic countries. One of the main ideas of Ukrainian political views is the predominance of the middle class in our country. But the most important is the state of current class struggle in Ukraine and the probability of the middle class winning.

The relevance of this research work consists in the prolonged crisis of political and socio-economic systems, which has lasted during recent years. The purpose of this analysis is the classification and description of the middle class formation and development peculiarities in Ukraine. To reach the stated purpose the following task was determined:

- To synthesize the results of the middle class researches in Ukrainian society.

The following Ukrainian analysts dedicated their works to theoretical and applied problems of the middle class research: Kutsenko O., Libanova E., Holovakha Y., Makieiev S., Shanhina L., Yakuba O., Dovbnia O., Kaspruk V., Aleksandrova O., Medvedenko I., Kovtunenko V., Vasyliev Y., Mikhel D., Lysenko L. and others.

Research works by Ukrainian analysts emphasize the criteria of social stratification of the middle class both quantitative economic indexes, for instance income level and its distribution, and qualitative characteristics of the middle class division, nature and content of labor, lifestyle, and stabilization role of the middle class in society dynamics. Nevertheless it is necessary to notice that presently there are not many systematic researches regarding formation and development of the middle class in Ukraine.

\section{Middle class in developed countries}

The notion of the middle class was used in research works of analysts from the west countries for defining the government officials and servicemen, teachers and professors, doctors, engineers, farmers, qualified workers of industrial sector that featured relatively high level of their life and social mobility in comparison to the working class. Later, the class of top managers was added to the middle class category.

The middle class in developed countries is able to realize its targets and bring them politically. Because of its strength, the middle class can prevail in a law system, political and religion organizations. As a result it mostly forms moral standards of society. It is needed to be mentioned that the middle class fulfills the row of separate functions.
Among them the following basic functions should be stated: regulation and stabilization function, function of economic donor and defining the character and structure of the consumer market.

Within present conception the middle class representatives use all civil rights, owe the relative income, do not conceal it and pay all the taxes. Furthermore, the financial stability of the middle class facilitates the national economic development, since the most representatives of this class keep their savings on bank's deposit accounts, buy shares, invest money etc. Social stability of the middle class representatives depends on prestigious education and professional job, as well as perspective of career ladder or own businesses.

On the whole, it can be asserted that the middle class representatives get their income owing to the higher education and working experience in professional field, further training that is also the reason they differ by stability. The system of living priorities of the middle class in developed countries is built up due to the scheme «education - job - income - status $»$. In developed countries the middle class is characterized not only due to its income level, but also lifestyle and separate consuming standards.

The middle class takes the leading place in political and economic development in democratic society. The middle class number was quickly increasing before the financial crisis, but stopped after 2007 (Credit Suisse Global Wealth Report, 2015).

Due to the Credit Suisse methodology the middle class number in west countries amounts to $35-65 \%$ of population (Table 1).

Table 1

Middle-class share of all adults (\%), 2015, by country and region

\begin{tabular}{|c|c|}
\hline & Middle class \\
\hline Belgium & 62.1 \\
\hline Italy & 59.7 \\
\hline United Kingdom & 57.4 \\
\hline Spain & 55.8 \\
\hline Netherlands & 54.1 \\
\hline France & 49.2 \\
\hline Canada & 47.8 \\
\hline Switzerland & 44.5 \\
\hline Austria & 44.0 \\
\hline Germany & 42.4 \\
\hline Denmark & 39.5 \\
\hline Sweden & 39.4 \\
\hline USA & 37.7 \\
\hline
\end{tabular}

Source: (Davies, Lluberas, Shorrocks, 2015)

\section{Current state of the middle class in Ukraine}

After the Soviet Union disintegrated on the first stage of reforming the birth of the powerful middle class, which would be able to perform its traditional functions, was forecasted in Ukraine. 
The society system transformation processes resulted into the drastic differentiation of the incomes of population and society stratification on the basis of social features. The very processes drew Ukrainian analysts' attention to the problem of finding out the resistant basics of the society social structure. An advent of the powerful middle class, which is believed to fulfil the economic donor and society stabilization functions, is considered by many analysts as the criteria of reform effectiveness and pledge of economic and social development.

The systematic financial and economic crisis that started in 2007 affected all countries of the world, but Ukraine suffered the most. The period from 2014 till 2015 was marked as the peak of economic recession for Ukraine. In 2015 the economy state in Ukraine did not change because of the political crisis and military actions started at the end of 2013. In 2014 GDP declined by 6,8\%, and rate of inflation amounted to $24,9 \%$ (State Statistics Service of Ukraine «Gross Domestic Product», 2014). In 2015 GDP decreased by $9 \%$, and the rate of inflation $-46 \%$. In accordance with the SSSU date, in summer of 2015 in comparison to spring, GDP of Ukraine rose by symbolic $0,7 \%$ (State Statistics Service of Ukraine «Change in the gross domestic product by $2015 \gg, 2015$ ). Two years ago it was the last time when economy of Ukraine showed the positive dynamics. It was in summer of 2013. IMF prognoses, that the planned positive dynamics in economy will bring the slight increase in 2016. According to the government and IMF evaluations, GDP of Ukraine will rise to $2 \%$, inflation will decrease up to $12 \%$, state fiscal deficit will be $3,7 \%$ of GDP.

Experts claim that in accordance with two main criteria, namely the level of living and education, the middle class amounts to about $10 \%$ of population. If one more defining characteristic is taken into account, namely the political views and activity, then the Ukrainian middle class will lose up to $5 \%$.

Taking into account the basic criterion of the middle class, its income, it has no sense to talk about this class in Ukraine. The annual wages of residents in modern Ukraine, who refer themselves to the middle level accordingly to the sociological researches, are around 60-100 thousand hryvnias per year (and that is in view of non-official wages) (Public organization «Development of the Middle Class $\gg, 2015)$.

The income, the basic part of which is wage, is one of the main indicators of living level of the population. Its amount depends on many activities characterizing the current state of economy in a country. At present days the economy of Ukraine is in a poor condition because of the military actions within its territories.

It is necessary to say that the analysis of nominal and real wages dynamics is very important. It should be noted that economy of Ukraine in 2014 tended to decrease nominal and real wages by $1,9 \%$ and $14,7 \%$ accordingly (Fig. 1). It is connected with the beginning of military actions on the territory of Ukraine, annexation of Ukrainian territories and political crisis in 2014. It is important to mention that in 2015 the level of nominal wage grew up to $14,5 \%$, since the real wage level had decline (by 13,7\%).

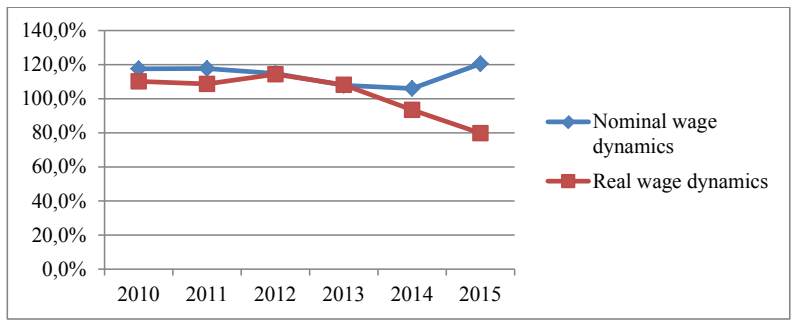

Fig. 1. Dynamics of wages during 2010-2015

Source: (State Statistics Service of Ukraine «Growth rates of nominal and real wages $\gg, 2010-2015$ )

It should be mentioned that particularly this period appeared to be crucial for Ukraine in its historical development. Ukrainian state, being under the influence of destabilizing external factors and destructive internal agents, is submerged into hazardous zone of instability. It prevents formation of the full middle social stratum.

The biggest part of Ukrainians that refer themselves to the middle class has their yearly income below 6000 dollars per year. That is an official established by U.N.O. breadline of inhabitants of Europe. In fact accordingly to the income level these people belong to the poorest social layers of the Ukrainian society. Daily they have to think not about cultural and intellectual development, but how to provide sustenance, and minimum of the needed for family.

The process of the middle class formation, which would meet the property status and personal incomes criteria of the developed countries, is on the initial stage. The reason is mainly the low living level of population. Furthermore, many people, who are not far from the middle class status, get the considerable part of incomes unofficially and do not pay taxes. It leads them to contradictory relations with the state, and consequently to difficulties on the way of social function realization, namely to be the basis of social stability.

One of the fundamental social problems of Ukraine consists in the absence of the developed civil society's ability to vindicate the interests of Ukrainian majority. The power is in hands of the oligarchic capital representatives. Financial and industrial groups perform unbalanced redistribution of the national product through the controlled political parties. The very activity caused the increasing of shadow economy by means of the tax overpressure of representatives of the small and middlescale businesses. Thus there are two simultaneous processes: enrichment of individuals and impoverishment of the most people. Financial and industrial groups prevent the competitiveness and equal terms of management. This system needs revolutionary changes. Without them it has no sense to talk about formation of adequate social politics in the field of building the sturdy social structure, where the middle class will prevail.

Now Ukraine is the state with repressive model of economy concerning business, which is oriented on 
monopoly. The main features of the repressive and monopolistic character of economy are: crippling taxes, excessive regulation and extensive control of entrepreneurship, existing of financial and industrial groups almost in every branch and sphere of economy, which together with the authority, control business as well as budgetary state and local funds, and redistribute for its own benefit the property and financial resources.

Spread of the «shadow» model of social and economic relationships resulted in limitation of legal employment and income possibilities, complicated development of the small-scale and middle businesses. As a result, the national middle class is factually deprived of one of the main statute features - possibility of protection the democratic rights and liberties, what led to narrowing of channels for the public politics realization. The amount of employers (natural persons) and owners of small businesses is constantly increasing. However, due to the unfavorable enterprising climate, the considerable part of small businesses has to shade.

It will not succeed in building adequate civil society, taking part in political and social life of state and able to control the authority, without adequate middle class in Ukraine. It is vital for Ukraine to have the capable middle class, representatives of which would take the most active part in social life, facilitate the development of the institutions of civil society, which are not dependent on direct intrusion of government. Owing to these institutions it will be possible to defend interests and influence on the state policy.

The specific feature of forming of the middle class in Ukraine is that, compared to the West-European countries, its basis is not owners, but specialists - employees, demand for which is the strongest in frames of innovative model of economy development. From the point of home experts' view, in Ukraine the export-oriented economy, which can be competitive on the foreign markets mostly due to the cheap workforce, has been forming during the long period of time because of various reasons. Hence we have the unique situation when the biggest part of highly-qualified

Table 2

Average wage in accordance with economic
activities per month in $\mathbf{2 0 1 6}^{\mathbf{1 , 2}}$
(per one member of staff, hrn.)
\begin{tabular}{|l|c|}
\hline \multicolumn{1}{|c|}{ Type of activity } & January \\
\hline Total & 4362 \\
\hline Education & 3178 \\
\hline $\begin{array}{l}\text { Care of public health and medical } \\
\text { aid providing }\end{array}$ & 2878 \\
\hline $\begin{array}{l}\text { National administration and defense; } \\
\text { compulsory social insurance }\end{array}$ & 4258 \\
\hline
\end{tabular}

${ }^{1}$ Excluding temporary occupancy of the Autonomous Republic of Crimea territories, of Sevastopol and some zones of anti-terrorist operations.

${ }^{2}$ Data are cited about judicial persons and separated subdivisions of judicial persons with number of employees 10 and more persons.

Source: (State Statistics Service of Ukraine «Average monthly wages by economic activity since the beginning of the year 2016», 2016) workers, who have to be the core of the middle class, are on the poverty verge or beyond it accordingly to the income level. The level of wages of such experts is even lower of middle through the country (Table 2).

One of the attributive characteristics of the middle class is high level of civil movement, which shows itself in different forms - from participation in elections of representative bodies and local authorities to amateur association with the purpose to protect the violated human as well as resident rights and liberties. The middle class can be considered as a social basis of civil society acting exactly as the subject of civil activity.

Showing of citizen's membership in political parties and civic organizations is an important indicator in analyzing the middle class development. At the same time these activities in Ukraine do not meet the standards of the European Union countries: by 10 thousand of population there are 11 registered organizations in Ukraine, since in Estonia - 201 organizations, in Croatia - 85 (The National Institute for Strategic Studies, 2012).

\section{Ways of solving}

Among the most important strategic priorities of successful modernization of Ukraine in near-term and longterm outlooks the forming of favorable entrepreneurial and investment climate can be singled out. At the same time it cannot be provided without improvement of government system in the sphere of entrepreneurship.

The following steps should be included into the basic strategic course of successful modernization of Ukraine:

- formation of the favorable entrepreneurial and investment climate.

- review of the regulatory and tax politics.

- providing fair competition.

- activation of innovative functioning of small and middle-scale enterprises.

- deregulation of small-scale business.

- lowering the taxation pressure upon small-sized business and population.

- increasing the living level of Ukrainians.

To develop the small-scale business it is needed to contribute to the whole economy. Concerning the smallsized, middle and big business an adequate economic policy is required. The main advantage of small and middle business is rather solving the employment problems and simultaneous providing steady income for workers, than paying taxes.

It is important for the government to realize that taxes for small and big business cannot be equal. It is gibberish. Taxes must be different; they should be collected and withheld in different ways. The only condition - there must be the right system of transition from the fixed taxes or simplified taxation system to the system, which would stimulate the change to pay significant taxes in case of business growth. This system must be flexible in order to incite the rise from low to middle and then to high level. 
Policy of facilitation of the middle class building-up in Ukraine has to rely on the support of working population, providing a great increase of wage, protection of intellectual property and reinforcement on these grounds the position of highly-qualified workforce as well as on support of the entrepreneurship. The formation of the middle class in Ukrainian society must be realized not through the creation of principally new social grouping, but through the gradual transformation of corresponding social groups and their way of functioning (Latik, 2008).

When considering the specialists as a basis of the Ukrainian middle class future, it is necessary to stress the significant role of the social politics. This group has the row of adequate important features, typical for the middle class of European type. All that is needed to provide the principle of social justice is to regenerate the occupational prestige through considerable wage rise.

\section{Conclusions}

The process of forming the middle class in Ukraine is characterized by contradictory tendencies. The positive conceptions of the middle class of Ukrainian citizens are tied up with their confidence that social and economic policy of government is not directed at its forming and support.

The unformed state of the middle class complicates the process of the formation of full-value civil society. It can be traced in low quantitative and qualitative indicators of the development of the latter and not high level of civil activity.

Whereas in countries of the West the middle class question basically confines to the political stability and effectiveness of democracy, in Ukraine it is also an indicator of society welfare. Small number of the middle class is caused by the absence of innovative productions, which could give people the prestigious, highly-qualified and well-paid workplaces.

Another reason consists in an uncompromising hostility of government to the small-sized and middle business, which is the potential source of wide self-employment. Reducing the middle class together with increasing the poor is quite a symptomatic tendency and requires the emergency measures as well as super efforts for reforming the economic model of the country.

Clannish-oligarchical regime, which has been formed in Ukraine, does not facilitate the establishment of small and middle class. Having excluded the acceptable conditions of business management, the governments, ignoring numerous legislative acts, made many Ukrainian businessmen break the law. That is why the politics of facilitating the formation of considerable advances and authoritative middle class in Ukraine have to base on the change of the strategy of social and economic improvement, creation of conditions for free entrepreneurship.

Entrepreneurial activity in forms of the small and middle business structures has a considerable potential for the middle class formation in Ukraine. Provided the gradual improvement of mechanisms of the state regulation, rise of the management level and professionalism in conducting the entrepreneurial activity, this potential can be transformed in realities. It is confirmed by the experience of developed countries with market economy. The effectiveness of overcoming the economic crisis consequences, further promotion of the country in a way of social and economic progress, European integration and strengthening its global competitiveness - all largely depend on the level of small and middle class development, the result of partner relationships between the government and business, consideration in full the interests of both sides.

The formation of the middle class with the help of state social policy must be implemented through the following priority directions:

- building the system of social protection;

- the organization of the institution of the middle class support;

- providing employment;

- increase of the human potential;

- formation of the labor potential.

The basis of the middle class must also be specialists representatives of the sphere of education, medicine, public management. Nowadays these groups pretend to be included into the middle class (by the education level, identification with the middle class), although the level of their material security does not correspond to their contribution into the state development.

Thus, the priority directions of the state policy concerning the formation of the middle class in Ukraine must be the strengthening of financial conditions by means of providing sufficient level of wages for specialists and highly-qualified workforce as well as supporting small and middle-scale business.

In case of the middle class development in Ukrainian society the conflict will be eradicated, which is typical for the bipolar social systems, and Ukraine will organically enter into the European community. If the amount of the middle class in society reduces, Ukraine can lose the basis of democratic development and social stability.

\section{References}

Credit Suisse Global Wealth Report (2015). - [Electronic resource]. - Retrieved from: https:// publications.credit-suisse.com/tasks/render/file/?fileID =F2425415-DCA7-80B8-EAD989AF9341D47E

James Davies, Rodrigo Lluberas and Anthony Shorrocks, Credit Suisse Global Wealth Databook (2015).

Latik,V. (2008). Peredumova demokratychnoyi perspektyvy. Suchasnist', №12.

Public organization «Development of the Middle Class» Manifest the middle class. - [Electronic resource]. Retrieved from: http://www.middleclass.org.ua/sredniy-klass-v-ukraine-tseli-i-zadachi/ 
State Statistics Service of Ukraine «Average monthly wages by economic activity since the beginning of the year 2016». - [Electronic resource]. -- Retrieved from: http://ukrstat.gov.ua/operativ/operativ2016/gdn/Zarp_ ek_p/zpp2016_u.htm

State Statistics Service of Ukraine «Change in the gross domestic product by $2015 »$. - [Electronic resource]. Retrieved from: http://ukrstat.gov.ua/operativ/operativ2015/vvp/ind_vvp/ind_2015_u_n.htm

State Statistics Service of Ukraine «Gross Domestic Product». - [Electronic resource]. - Retrieved from: http://www.ukrstat.gov.ua/operativ/operativ2005/vvp/vvp_ric/vvp_u.htm

State Statistics Service of Ukraine «Growth rates of nominal and real wages». - [Electronic resource]. - Retrieved from: http://www.ukrstat.gov.ua/operativ/operativ2005/gdn/tznr/tznr_u/tznr_u_bez.htm

The National Institute for Strategic Studies «The problems of the middle class as the foundation of civil society in Ukraine». - [Electronic resource]. - Retrieved from: http://www.niss.gov.ua/articles/265/

\section{Яна САЛО}

\section{АНАЛИЗ СОСТОЯНИЯ И ПЕРСПЕКТИВЫ РАЗВИТИЯ СРЕДНЕГО КЛАССА В УКРАИНЕ}

Аннотация. Целью работы является исследование современного состояния среднего класса в Украине, проблемы его становления и перспективы развития в будущем с определением взаимодополняющего комплекса внутренних и внешних факторов его формирования. Методика. Исследование основано на статистической информации из открытых официальных источников, которая даёт возможность подтвердить тезисо критическойдолисреднего классав Украине.Данныетакжебылиполучены изэлектронныхисточников Государственной службы статистики Украины. Во время исследования вопроса также использовались аналитические экономические статьи по вопросам развития среднего класса в Украине. Результаты исследования показали, что в современной Украине численность среднего класса является критически низкой для стабильного функционирования экономики. Одной из главных проблем развития среднего класса является отсутствие государственного содействия развитию малого и среднего бизнеса. В Украине сформировано государство с репрессивной моделью экономики в отношении бизнеса, ориентированной на монополизацию. Распространение «теневой» модели общественно-экономических отношений приводит к ограниченности легальных возможностей занятости и доходов, осложняет развитие малого и среднего бизнеса. Как следствие, количество предпринимателей и владельцев малых предприятий постоянно растёт, но из-за отсутствия благоприятного предпринимательского климата значительная часть малых предприятий вынужденно переходит в тень. Особенностью формирования среднего класса в Украине является то, что его социальной основой, в отличие от западноевропейских стран, является не владельцы, а специалисты наемные работники. Имеем уникальную ситуацию, когда большая часть высококвалифицированных работающих (представителей сферы образования, здравоохранения, государственного управления), которые должны составлять ядро среднего класса, по уровню доходов находятся на грани или за чертой бедности. Уровень заработной платы таких специалистов даже не является средним по стране. Практическое значение. На пути к успешной модернизации Украины в краткосрочной и долгосрочной перспективе важнейшими приоритетами является благоприятный предпринимательский и инвестиционный климат. Это, в свою очередь, невозможно осуществить без усовершенствования системы государственного управления в сфере предпринимательской деятельности. Политика содействия формированию среднего класса в Украине должна опираться на поддержку работающего населения, обеспечение опережающего роста зарплаты, укрепление положения высококвалифицированной рабочей силы, а также на поддержку предпринимательства. Становление среднего класса в украинском обществе должно происходить не путем создания принципиально новой социальной группы, а с помощью постепенной трансформации соответствующих социальных групп и способа их жизни. Значение/оригинальность. Исследование было проведено для более четкого понятия состояния среднего класса в Украине. Были выделены причины столь низкого уровня среднего класса в Украине на основе полученных данных. Полученные в результате исследования выводы дают возможность предложить мероприятия для развития среднего класса в Украине, а именно - развитие малого и среднего бизнеса и поддержка работающего населения с учётом интересов представителей среднего класса. 